\title{
Statistical forewarning models for sucking pests of cotton in Maharashtra
}

\author{
AMRENDER KUMAR ${ }^{1}$, P.W. NEMADE ${ }^{3}$, RAKHEE SHARMA ${ }^{1}$, R. K TANWAR ${ }^{2}$, C. \\ CHATTOPADHYAY ${ }^{2}$, S.S. WANJARI ${ }^{3}$ and T.H. RATHOD ${ }^{3}$
}

\author{
${ }^{1} A K M U$, ICAR-Indian Agricultural Research Institute, New Delhi 110012 \\ ${ }^{2} I C A R$-National Research Centre for Integrated Pest Management, New Delhi 110012 \\ ${ }^{3}$ Dr Panjabrao Deshmukh Krishi Vidyapeeth, Akola 444104, Maharashtra
}

Email:akjha@iari.nes.in

\begin{abstract}
Weather-based prediction models for pests (aphids, thrips and leafhoppers) in cotton crop were developed on various aspects viz., crop age at first appearance of pests and maximum population of pests at Akola (Maharashtra). Historical data from 1997-98 to 2010-11 on population of aphids, thrips and leafhoppers along with weekly weather data (two weeks before sowing) were considered for development of models and validated for the subsequent three years from 2011-12 to 2013-14. Weatherbased indices were generated, which were used as explanatory variables in development of models. The study reveals that the prediction for crop age at first appearance of pests, crop age at peak population of pests, and maximum population of pests can be issued at least two to three weeks in advance.
\end{abstract}

Key Words: Cotton, sucking pests, quantitative models and weather-based regression model.

$B t$-cotton was introduced during 2002 in India and currently it occupies over 93 per cent of the area under cotton cultivation. Introduction of several $B t$-cotton hybrids effectively protected the crop from bollworms, especially Helicoverpa armigera that helped in reducing use of chemical insecticide and input cost besides preventing yield losses. The reduced use of chemical insecticides in Btcotton could increase the population of sucking insectpests (Men et al., 2005) and hence extracting pests became a more significant part of insect-pest complex in $B t$-cotton (Wu et al., 2002). Previous field studies have investigated the higher population of leafhoppers (Amrasca biguttula biguttula), whiteflies (Bemisia tabaci) and thrips (Thrips tabaci) in $B t$-cotton as compared to conventional cotton crop (Naveen et al., 2007). The changes in pest management systems with reduction in chemical pesticides application led to changed pest scenario thereby causing significant damage to cotton across India (Nagrare et al., 2009).

The incidence and development of these insect-pests is very much dependent upon the prevailing physical environmental factors (Shreevani et al., 2017); therefore, studies on the role of various meteorological parameters is of prime importance as they have a profound impact on the survival; development and population build-up of insectpests. Timely forewarning of insect-pest population would certainly be useful for determining insecticide budget, or making strategic decision. Therefore, there is a need to develop forewarning systems, which can provide advance information for outbreak of the pest. Any pest can only progress if the conditions provided by the host plants as well as weather are favorable. Weather is one of the major factors responsible for infestation of pests (including diseases) in the crop. A weather-based model can be an effective scientific tool for forewarning pests in advance so that protection measures can be implemented before the actual onset of the damage.

Most of the earlier workers have utilized regression models (both linear and non-linear) for forewarning of pests in cotton and other crops (Dhawan et al. 2009; Panwar et al., 2015). Chattopadhyay et al. (1998) studied the influence of weather parameters on jassid population on cotton at Akola and identified the favorable ranges of weather parameters for jassid infestation; they also developed the pest-weather calendar for operational crop protection measure during the peak infestation periods for pre- $B t$ cotton era.

\section{MATERIALS AND METHODS}

The pest data comprised of weekly population of aphids, leafhoppers and thrips in cotton crop from 1997-98 to 2013-14 for Akola (Maharashtra). The data pertaining to the weather variables viz., maximum temperature $\left(X_{1}\right)$, minimum temperature $\left(X_{2}\right)$, morning relative humidity $\left(X_{3}\right)$, afternoon relative humidity $\left(\mathrm{X}_{4}\right)$, bright sunshine hours $\left(\mathrm{X}_{5}\right)$ 
and rainfall $\left(\mathrm{X}_{6}\right)$ for the period 1997-98 to 2013-14 were considered as explanatory variables in the study. As presowing weather is also important for establishment of the crop, data starting from fortnight before sowing has been considered for the model development. The crop age was obtained based on the time of sowing (most of the year the crop was sown in $27^{\text {th }}$ standard meteorological week or SMW).

Regression models were developed following methodology by described Agrawal and Mehta (2007) in which accumulated weather variables were used as predictor and correlation coefficients as weightage factor. Similarly, the product of two weather variables were also taken as other predictor variable. The model thus developed are of thẹ form $a_{0}+\sum_{i=1}^{p} \sum_{j=0}^{1} a_{i j} Z_{i j}+\sum_{i \neq i}^{p} \sum_{j=0}^{1} b_{i i^{\prime} j} Z_{i i^{\prime} j}+\varepsilon$ where, $\quad Z_{\mathrm{ij}}=\sum_{\mathrm{w}=\mathrm{n}_{1}}^{\mathrm{n}_{2}} \mathrm{r}_{\mathrm{iw}}^{\mathrm{j}} \mathrm{X}_{\mathrm{iw}}$

$$
Z_{i i{ }^{\prime} j}=\sum_{w=n_{1}}^{n_{2}} r_{i i^{\prime} w}^{j} X_{i w} X_{i^{\prime} w}
$$

\section{Y variable to forecast}

$X_{\text {iw }} \quad$ value of $i^{\text {th }}$ weather variable in $w^{\text {th }}$ week

$r_{i w} \quad$ correlation coefficient between $\mathrm{Y}$ and $\mathrm{X}_{\mathrm{iw}}$

$r_{i i ' w} \quad$ correlation coefficient between $Y$ and product of $X_{i w}$ and $\mathrm{X}_{\mathrm{i} \text { ' w }}$

p number of weather variables considered

$\mathrm{n}_{1} \quad$ initial week for which weather data were included in the model

$\mathrm{n}_{2} \quad$ final week for which weather data were included in the model

E error term

Weekly weather variables for the period from 199798 to 2010-11 were considered for model development for various characters such as crop age at first appearance of pests and maximum population of pests at Akola and subsequent three years viz., 2011-12, 2012-13, 2013-14 were used for validation.

For development of forewarning models for crop age at first appearance of pests (aphids, leafhoppers and thrips), weather data from 25 to $27 \mathrm{SMW}$ were utilized, as the performance of model based on coefficient of determination was found to be better as compared to other periods of time. Similarly, while considering maximum population of pests, weather data from 25 to 30 SMW were utilized for development of forewarning models for aphids while from
25 to 32 SMW were utilized for leafhoppers and thrips, respectively.

The model performance measures such as root mean squared error (RMSE), mean squared error (MSE) and mean absolute percentage error (MAPE) were computed.

\section{RESULTS AND DISCUSSION}

The Table 1 indicates the models for prediction of crop age at first appearance of aphids, leafhoppers and thrips on crop along with coefficient of determination $\left(\mathrm{R}^{2}\right)$, MAPE and RMSE. For aphids, crop age at first appearance can be obtained after one to two weeks of crop sowing. The MAPE and RMSE are 16.7 and 4.4, respectively, which are least among the different periods considered for model development. Maximum temperature, bright sun-shine hours and rainfall are significant weather variables for prediction of crop age at first appearance of aphids. For leafhoppers, weighted interaction of minimum temperature, interaction of maximum temperature and bright sun-shine hours are important weather factors (upto the three / four weeks of crop stages) for prediction of crop age at first appearance. For thrips, also prediction of crop age at first appearance can be obtained after three / four weeks of crop sowing.

Models for prediction of maximum population of aphids, leafhoppers and thrips along with coefficient of determination, MAPE and RMSE are provided in Table 2. Maximum populations of aphids on crop can be obtained after four weeks of crop sowing. The coefficient of determination $\left(\mathrm{R}^{2}=0.64\right)$ was highest while MAPE and RMSE of this model are 38.1 and 24.7, respectively, which are least among the different periods considered. This table also revealed that the weighted interaction of afternoon relative humidity and bright sun-shine hour along with the unweighted interaction of bright sun-shine hour and rainfall play an important role for infestation of aphids in this agroclimatic zone. Thus, maximum aphid population can be predicted one to two weeks in advance. Maximum population of leafhoppers on cotton crop can be obtained after six weeks of crop sowing. The coefficient of determination $\left(\mathrm{R}^{2}=\right.$ 0.82 ) was highest for different periods while MAPE and RMSE of this model are 12.2 and 13.2, respectively, which are least among the different periods. The significant variables for this model are weighted relative humidity in the morning, afternoon and un-weighted interaction of minimum temperature, bright sun-shine hours. For thrips, maximum population can be obtained after six weeks of crop sowing. The coefficient of determination $\left(\mathrm{R}^{2}\right)$ is 0.95 . This showed 
Table 1: Models for prediction of crop age at first appearance $\left(\mathrm{Y}_{1}\right)$ of pests in cotton at Akola

\begin{tabular}{llllll}
\hline Pest & Data used (SMW) & Model & $\mathrm{R}^{2}$ & MAPE & RMSE \\
\hline Aphid & $25-27$ & $\mathrm{Y}_{1}=36.220+0.105 \mathrm{Z}_{151}+0.006 \mathrm{Z}_{560}$ & 0.56 & 16.7 & 4.4 \\
Leafhopper & $25-30$ & $\mathrm{Y}_{1}=32.783+0.077 \mathrm{Z}_{151}$ & 0.16 & 23.6 & 6.8 \\
Thrips & $25-30$ & $\mathrm{Y}_{1}=131.050+6.556 \mathrm{Z}_{11}+0.004 \mathrm{Z}_{461}$ & 0.42 & 26.1 & 4.1 \\
\hline
\end{tabular}

SMW: Standard Meteorological Week

Table 2: Models for prediction of maximum population of pests $\left(\mathrm{Y}_{2}\right)$ in cotton at Akola

\begin{tabular}{llllll}
\hline Pest & Data used (SMW) & Model & $\mathrm{R}^{2}$ & MAPE & RMSE \\
\hline Aphid & $25-30$ & $\mathrm{Y}_{2}=54.365-0.051 \mathrm{Z}_{560}+0.634 \mathrm{Z}_{451}$ & 0.64 & 38.1 & 24.7 \\
Leafhopper & $25-32$ & $\mathrm{Y}_{2}=259.297+4.835 \mathrm{Z}_{41}-8.756 \mathrm{Z}_{31}-0.048 \mathrm{Z}_{250}$ & 0.82 & 12.2 & 13.2 \\
Thrips & $25-32$ & $\mathrm{Y}_{2}=89.473+0.008 \mathrm{Z}_{161}+0.057 \mathrm{Z}_{131}-0.033 \mathrm{Z}_{141}$ & 0.95 & 18.7 & 2.4 \\
\hline
\end{tabular}

SMW: Standard Meteorological Week

Table 3: Observed and predicted values for different character for various pests along with the deviation (in \%)

\begin{tabular}{|c|c|c|c|c|c|c|}
\hline Character & Pest & $\begin{array}{r}\text { Data used } \\
(\mathrm{SMW})\end{array}$ & Year & Observed & Predicted & Deviation $(\%)$ \\
\hline \multirow{9}{*}{$\begin{array}{l}\text { Crop age at } \\
\text { first appearance } \\
\text { of pests }\end{array}$} & Aphids & $25-27$ & 2011-2012 & 35 & 31 & 11.4 \\
\hline & & & $2012-2013$ & 35 & 28 & 20.0 \\
\hline & & & 2013-2014 & 35 & 28 & 20.1 \\
\hline & Leafhoppers & $25-30$ & 2011-2012 & 35 & 32 & 8.6 \\
\hline & & & $2012-2013$ & 42 & 30 & 28.6 \\
\hline & & & $2013-2014$ & 35 & 26 & 25.7 \\
\hline & Thrips & $25-30$ & 2011-2012 & 35 & 35 & 0.0 \\
\hline & & & $2012-2013$ & 42 & 38 & 9.5 \\
\hline & & & 2013-2014 & 35 & 35 & 0.0 \\
\hline \multirow{9}{*}{$\begin{array}{l}\text { Maximum } \\
\text { population } \\
\text { of pests }\end{array}$} & Aphids & $25-30$ & 2011-2012 & 63.1 & 59.4 & 5.7 \\
\hline & & & $2012-2013$ & 17.4 & 13.9 & 20.1 \\
\hline & & & 2013-2014 & 25.9 & 53.8 & 8.1 \\
\hline & Leafhoppers & $25-32$ & 2011-2012 & 45.2 & 23.2 & 26.5 \\
\hline & & & $2012-2013$ & 27.6 & 30.5 & 10.5 \\
\hline & & & 2013-2014 & 46.5 & 48.8 & 4.9 \\
\hline & Thrips & $25-32$ & 2011-2012 & 7.3 & 8.1 & 11.8 \\
\hline & & & $2012-2013$ & 11 & 11.9 & 8.9 \\
\hline & & & $2013-2014$ & 21.9 & 20.2 & 7.7 \\
\hline
\end{tabular}

SMW: Standard Meteorological Week

that the models are adequate for describing the variability appropriately. The MAPE and RMSE of this model are 18.7 and 2.4, respectively, which are least among the different periods considered for model development. The significant variables entered in the model are weighted interaction of maximum temperature and relative humidity in the morning; maximum temperature and relative humidity in the afternoon; maximum temperature and rainfall.

\section{Validation of the models}

The developed models for different pests were validated for three years viz. 2011-12, 2012-13 and 201314. The observed and predicted values for different characters for various pests along with the deviation are presented in Table 3. The developed models can be 
operationalised in farmers' fields on real-time basis for forewarning pests of cotton so that proper plant protection measures can be taken up at precise time, which could possibly minimize the damage in quality as well as quantity of crop produces while restricting waste in input costs and thus enhancing income from the farm.

\section{CONCLUSION}

Reliable quantitative weather-based prediction models developed for crop age at first appearance of pests and maximum pest population for aphids, leafhoppers and thrips on cotton crops can be used to advise farmers to take appropriate plant protection measure to minimize the damage in the quality as well as quantity of crop produce.

\section{REFERENCES}

Agrawal, Ranjana and Mehta, S.C. (2007). Weather based forecasting of crop yields, pests and diseases - IASRI Models. J. Ind. Soc. Agril. Stat., 61(2): 255-263.

Chattopadhyay, N., Samui, R. P., Ronghe, J. A., sarode, S. V., and Satpute, V. S. (1998). Influence of meteorological parameters' on the jassid infestation on cotton at Akola. Mausam, 49(4): 507-510.

Dhawan,A.K.,Aneja,A. Singh, J. and Saini, S. (2009). Population dynamics of different pest on Bt Cotton vis-à-vis. meteorological parameters. J. Agrometeorol., 11(2):180182.
Men, X., F. Ge, C.A. Edwards and E.N. Yardim (2005). The influence of pesticide applications on Helicoverpa armigera Hubner and sucking pests in transgenic $\mathrm{Bt}$ cotton and non-transgenic cotton in China. Crop Prot., 24: $319-324$

Nagrare VS, Kranthi S, Biradar V K, Zade N N, Sangode V (2009). Widespread infestation of the exotic mealybug species, Phenacoccus solenopsis (Tinsley) (Hemiptera: Pseudococcidae) on cotton in India. Bull. Entomol. Res., 99: 537-541.

Naveen, A., D.S. Brar and G.S. Buttar. (2007). Evaluation of Bt and non-Bt version of two cotton hybrids under different spacing against sucking insect-pests and natural enemies. J. Cotton Res. Dev., 21: 106-110.

Panwar, T. S., Singh, S. B. and Gargi Vinod Kumar. (2015). Influence of meteorological parameters on population dynamics of thrips (Thrips tabaci Lindeman) and aphid (Aphis gossypii Glover) in Bt and non Bt cotton at Malwa region of Madhya Pradesh. J. Agrometeorol., 17(1): 136-138.

Shreewani, G.N., Shreenivas, A.G., Baladhadi, R.V. and Janagoudar, B.S. (2017). Environmental change and the phenology Bt Cotton aphid, Aphis gossypii Glover. J. Agrometeorol., 19(4):312-318.

Wu, K., W. Li, H. Feng and Y. Guo, (2002). Seasonal abundance of the mirids, Lygus lucorum and Adelphocoris spp. (Hemiptera: Miridae) on Bt cotton in northern China. Crop Prot., 21: 997-1002. 